\title{
Victims or intruders? Refugee portrayals in the news in Turkey, Bulgaria and the UK
}

Media, War \& Conflict 202 I, Vol. I4(3) 282-302 (C) The Author(s) 2021

Article reuse guidelines: sagepub.com/journals-permissions DOI: I0.II77/I75063522II0I3482 journals.sagepub.com/home/mwc

(\$SAGE

\author{
Emel Ozdora-Aksak $(\mathbb{D}$
}

Bilkent University, Ankara, Turkey

\section{Colleen Connolly-Ahern}

Penn State University, University Park, USA

\section{Daniela Dimitrova}

lowa State University, Ames, USA

\begin{abstract}
News shapes audiences' views of people and events beyond their immediate physical environment. Since the mass migration of refugees from Syria represents one of the worst humanitarian crises in modern history, its news coverage necessarily shaped the way global audiences understood the crisis. This qualitative study employs critical discourse analysis (CDA), specifically Van Leeuwen's Discourse and Practice: New Tools for Critical Discourse Analysis (2008) as a social practice approach, to reveal and compare the discursive strategies used in the print media coverage of the Syrian refugees in three European countries: Turkey, Bulgaria and the UK. The findings show significant differences in the discourse used to describe the refugees and different approaches in terms of contextualization, spaces and actions depicted in the media coverage in each country. The study reveals the ongoing dialogue between journalistic practice and political decision making in three countries impacted to varying extents by the ongoing crisis.
\end{abstract}

\section{Keywords}

Bulgaria, Critical Discourse Analysis (CDA), media, participation and agency, refugees, Turkey, UK

\section{Corresponding author:}

Emel Ozdora-Aksak, Bilkent University, Ankara 06800, Turkey.

Email: emel.ozdora@bilkent.edu.tr 


\section{Introduction}

According to the UNHCR's High Commissioner, Syria represents the largest humanitarian crisis of our time (UNHCR, 2020). In the aftermath of the Syrian Civil War, Turkey has housed a total of 3.6 million Syrian nationals as a result of its open-door policy (UNHCR, nd). Its neighbour to the west, Bulgaria, has accepted a lower number of refugees, with the latest statistics indicating that nearly 60,000 migrants have applied for asylum in Bulgaria since 2013 (Ivanova, 2018). In general, Bulgaria is seen as the entry point of the European Union (EU) and a transit country on the way to the economically developed Western European countries such as Germany. The UK, now officially out of the EU, has resettled only about 15,000 Syrian refugees under the Vulnerable Persons Resettlement Scheme, with a target of 20,000 by 2020 (Sturge, 2019). This article seeks to identify discursive structures and journalistic practices related to these vastly different governmental responses to the same humanitarian crisis.

While the number of refugees coming to Europe fluctuates from year to year, the refugee crisis has become a central point of political discourse across the region since it erupted in the early 2010s. In addition to political parties and politicians, starting from the beginning of the Syrian conflict, the news media have been one of the main vehicles influencing public opinion about the refugees (Ivanova, 2018; Onay-Coker, 2019; Polat and Kaya, 2017), often portraying refugees in a negative light either as victims or as a threat to the host countries (Baker et al., 2008; Gabrielatos and Baker, 2008; KhosraviNik, $2009,2010)$. Language used by the media not only shapes the decoding of messages, but also fosters the desensitization of audiences (Sajir and Aouragh, 2019). Thus, we examined the early representation of migration between the years 2011-2014 as that could be a benchmark for how the media cover the issue in the future. The three countries represent three different socio-political contexts that allow us to develop comparative insights on how the news media reflect and reinforce dominant cultural discourses. Turkey was chosen as it is the country hosting the largest number of Syrian refugees in the World (UNHCR, 2020). Bulgaria was selected as Turkey's neighbour and also a border country - one of the first entry points to the EU for Syrian refugees. It was also important to include a country such as Bulgaria that has little experience with migration and serves as an outside border of the EU. According to World Bank statistics, immigration in Bulgaria increased significantly from 2010 to 2015, by 33.85 percent (MacroTrends, 2021). While a specific breakdown per year and by country is challenging to provide because of illegal migration, official immigration statistics show the following numbers for non-EU migration: 16,615, 19,678 and 28,727 for 2012, 2013 and 2014, respectively (Bulgarian Statistical Institute, 2020). The UK was purposefully included to ensure that a country that is much less affected by the crisis was included. The UK, also being an island, made this distinction even physically more relevant. As suggested by Burscher et al. (2015), studying media coverage of immigration and its effects on public perceptions and attitudes may foster an understanding of migration policy changes across EU countries and the rise of anti-immigration politics.

Based on a qualitative analysis, the study adopts Van Leeuwen's (2008) discourse as a social practice approach to reveal and compare the discursive strategies used in the media coverage of the Syrian refugees in the three countries. Following Shirazi (2013: 
36), this study adopts 'a social perspective in the cross cultural study of media texts', and aims to compare and contrast the major discursive strategies used in the media coverage of Syrian refugees in the three countries. The main purpose of the study is to reveal the different types of refugee representations in a selected sample of newspapers from three different countries: Turkey (Hurriyet and Cumhuriyet), Bulgaria (Dneven Trud and Standard) and the UK (The Guardian). By comparing the news coverage side by side, we were able to uncover the boundaries of narrative contextualization and the level of agency given to refugees in their discursive representation across the three nations which have been affected by Syrian refugees differently and at different levels. We use CDA and recontextualization as a social practice framework developed by Van Leeuwen (2008) to answer this overarching research question: What type of discursive representations of refugees are commonly used in news stories from Turkey, Bulgaria and the UK, and how do these representations differ across the three countries?

Specifically, we ask:

RQ1: What linguistic terms are used to refer to actions related to refugees in the news?

RQ2: What discursive strategies are used to refer to representation of refugees as actors?

\section{RQ3: Which locations and spaces are referenced in the news stories?}

RQ4: What recontextualization strategies such as substitution, rearrangement, deletion and addition have been used in the news stories?

\section{Theoretical background}

This study focuses on the early period of the Syrian refugee movements between 20112014, before it turned into the Syrian refugee crisis. What has been referred to as the Syrian refugee crisis was initiated by the heart-breaking photo of the 3-year-old Syrian boy Alan Kurdi's lifeless body lying on a beach on the Mediterranean coast of Turkey in early September 2015, which has stirred up both the panic of a crisis hitting Europe (Sajir and Aouragh, 2019) and international sympathy for refugees, causing countries such as Austria and Germany to open up their borders for refugees 'to avoid a humanitarian disaster' (Tavassoli et al., 2019: 65). Studying journalistic practices surrounding refugees and asylum-seekers reveals the media's ongoing dialogue with societal power structures, particularly in their reliance on governmental sources. This is why refugees, immigrants and asylum seekers have featured prominently in previous discourse analysis investigations. Kirkwood et al. (2016), for example, assert that an understanding of language use in media coverage is critical to study the 'journeys' of asylum-seekers and refugees. Such an analysis can reveal the broader social and cultural context of media institutions that present an often inaccurate and mostly negative picture of refugees, which in turn shape policy responses, public opinion about the refugees and their lives at the local level. Uncovering discourses by analysing language is important for studying media texts as language is a form of social action with practical implications for people's lives 
(Burr, 1995) that constructs the experience of reality for people (Willig, 2013), further positioning readers/viewers towards the issue at hand (Tavassoli et al., 2019), influencing their attitudes and naturalizing underlying ideologies (Van Dijk, 2001a).

The study of language vis-à-vis representation of refugees by the media is critical since language does not merely describe but also constructs versions of identities and social groups (McKinlay and McVittie, 2011). Such representations may construct 'us' and 'them' groupings (Van Dijk, 1998), where 'us' is usually associated with positive and 'them' with negative assessments, which has been referred to as 'othering' (Tavassoli et al., 2019). Immigrants are constructed as a collective, 'a homogeneous group that represents a threatening "other" against which societal identity is constituted' (Innes, 2010: 462). According to Bozdag and Smets (2017: 4049), mass media perpetuates the 'otherness' of Syrian refugees by presenting them as 'victims, burdens, or threats'. Marginalization of 'the other' occurs through stereotyping, generalizations and fear of the newcomer (Bilge, 2019). This notion of 'othering' has been discussed in recent studies using CDA methodology (see, for example, Baker et al., 2008; KhosraviNik, 2009, 2010; Parker, 2015), some of them specifically focusing on the media representation of Syrian refugees, presenting them as the other or as out-groups (Aarssen, 2017; Yaylaci and Karakus, 2015). As suggested by Efe (2019: 50), 'inconsistent discourses regarding refugees and asylum seekers feed on existing fears and anxieties about "the other" and media plays a significant role in shaping and reproducing how people understand this important issue.' Thus, discourse analysis reveals power structures in regard to agency, access and participation, unmasking dominant ideologies that shape people's conceptualizations of ethnic groups, including refugees (Van Dijk, 1987). Studying media texts is important for understanding discourses at play in order to uncover these implicit and explicit power structures, agency for representation and active participation in the news discourse, and further reveal the positions of 'symbolic elites' such as politicians, journalists and scholars, who mainly control mass public discourses through the re/production of hegemonic narratives and dominant ideologies in mass communication (Van Dijk, 2005).

Previous studies document that media often portray migration through negative and divisive narratives, and a crisis mentality (Esses et al., 2013) that represent refugees as threats to the security, welfare and culture of the host societies. Research has revealed that mass media institutions may establish misconceptions of criminality or connection to crime through their representation of migrants (Berry et al., 2015; Esses et al., 2013; Larsen, 2008; Lawlor, 2015; Sohoni and Sohoni, 2014; Tavassoli et al., 2019; Tong and Zuo, 2019), framing them as cultural, economic and even physical threats (Eberl et al., 2018; Lawlor, 2015), sometimes associating migrants or refugees with violence through the stigmatization of Islam (Hoewe and Bowe, 2018). Public opinion research indicates there has been an increase in negative attitudes towards asylum seekers across Europe, linking them to delinquency, criminality and terrorism, and consequently perceiving them as security threats at personal and national levels (Bigo, 2002; D'Appollonia, 2012; Humphrey, 2013). These personal and national security threat perceptions have been seen as the root for exclusionary sentiments towards refugees (Canetti-Nisim et al., 2008; Fitzgerald et al., 2012), and have been countered by those who support humanitarian approaches and see helping those in distress or suffering as their moral duty (Gibney, 
2004). In a recent comparative content analysis between Turkish and Bulgarian media, Dimitrova et al. (2018) revealed that refugees were mostly framed as a threat to society, especially in Bulgaria. Turkish newspapers, in contrast, often adopted a humanitarian frame, included personal stories and portrayed refugees as victims that need aid. A corpus linguistics and CDA of over 2,300 Turkish news articles between 2011-2015 by Efe (2019: 48) revealed differing discourses, framing Syrians as 'our brothers', 'victims', 'needy people' and/or 'threat', 'criminals' etc., maintaining 'one or a combination of these discourses to construct their own reality about the refugee crisis in Turkey'. Thus, as suggested by Tavassoli et al. (2019: 76), this study aims to understand meanings conveyed by mass media representations of Syrian refugees in three different countries, their relations to institutional and political contexts, and wider public discourses as well as social changes they may trigger in terms of policy decisions and public opinion change.

\section{Methodology}

CDA is the systematic and explicit study of texts to understand structures and strategies, to uncover implicit power structures and ideologies at play, and to provide a certain perspective about a topic or phenomenon (Van Dijk, 1998). Cap (2017: 26) suggests CDA explores how 'ideologies and identities are reflected, (re)-enacted, negotiated, modified, reproduced' and uncovers the 'structural relationships of dominance, discrimination, power and control, as they are manifested in language' (Gabrielatos and Baker, 2008: 280). News stories about refugees were analysed to reveal how discourse is integrated as social practice inside these texts and were studied according to Van Leeuwen's (2008) discourse as a social practice approach for analysing the representation of refugees.

As Fairclough (1992) argued, understanding a text, its context and the meaning(s) it evokes for readers is important for understanding the discourse as a whole as well as the power structures at play within the text. Critical discourse analysis (CDA) requires the investigation of the use of language, studying texts to unearth the deeper systematic structures as well as the power relations that underlie discourse (Cukier et al., 2008). The CDA approach adopted here uses components from Van Leeuwen's (2008) discourse as social practice approach to analyse the representation of refugees as 'others' in news stories in national media. The actions that define what refugees do were examined to understand activities they are associated with. The actors/participants involved in the news stories used the following categories suggested by Van Leeuwen: collectivization vs individualization, spatialization through providing place or location, nomination through referral by names and titles, relational identification through the emphasis of who they are such as mother, daughter, etc. and lastly classification, which defines how they are classified. The locations in news stories were studied to reveal locations (such as camps) refugees are associated with.

In addition, Van Leeuwen's (2008) recontextualization of social practice categories was used to categorize news stories about refugees and reveal their access to and presence in the texts, and their agency to influence their own representation, which included: substitution, rearrangement (of events and narratives for a purpose), deletion (focusing on what is missing from the texts) and, lastly, addition. Substitution as a recontextualization of social practice takes place when certain elements of a social 
practice such as participants, times, spaces and actions are substituted by something else. Rearrangement can be explained as reorganizing some elements of the social practice to better serve the intended discourse. Revealing deletions in the news stories involves exposing what is missing from the data or what is excluded because it is not deemed relevant or even appropriate by a certain discourse. Additions are discursive strategies used in texts to highlight certain components: repetitions, reactions, goals and purposes, legitimation and evaluations (De Rycker and Don, 2013; Van Leeuwen, 2008).

The study focuses on the time period immediately after the Syrian refugee crisis started, covering the years 2011 to 2014, including stories that cover the beginning of the civil war in Syria and include the most active first three years of the crisis. Two popular and highly reputable daily newspapers from Turkey (Hurriyet and Cumhuriyet), Bulgaria (Dneven Trud and Standard) and one from the UK (The Guardian) were analysed through a discourse analysis to reveal and compare the discursive representation of refugees in three countries.

Research reveals that specific interest and political inclinations of newspapers may impact coverage, thus while pro-governmental newspapers may contain self-construction or defensive approaches about Syrian refugees, oppositional papers may contain critical arguments (Efe, 2019). Consequently, the newspapers we selected for the analysis from Bulgaria and Turkey consist of one mainstream popular newspaper and one critical left-wing newspaper to provide two different opinions about the refugee issues. The first Bulgarian newspaper analysed is the Standart ('Standard' in English), one of the top five dailies in the country, known for being a centre-left newspaper. The second paper examined, Dneven Trud ('Daily Labour' in English), is one of the oldest Bulgarian newspapers with a centre-right and close alignment to business interests. While reliable circulation numbers for Bulgarian newspapers are hard to locate, cross-referencing shows that Dneven Trud remains the highest circulation newspaper in the country, while Standart is another popular daily newspaper with a long-established journalistic tradition (Bulgarian Newspapers Online, nd).

The first Turkish newspaper studied is one of the oldest in the country, Cumhuriyet ('Republic' in English), a centre-left paper with a strong secularist and anti-government position which we believed could represent the oppositional perspectives about the Syrian refugees. The second paper Hurriyet ('Freedom' in English) is a popular centreright mainstream Turkish newspaper founded in 1948 with a high daily circulation and mainly pro-government point of view.

In contrast with the reporting from heavily impacted countries, this study also included analysis of one newspaper from a lightly impacted country, the UK, The Guardian. The Guardian's website is the UK's biggest newspaper website with about 13.9 million views per day (Turvill, 2020). Its print edition has a circulation over 125,000 and it is known as a mainstream centre-left newspaper with a socially liberal editorial policy.

The inclusion of only one centre-left news source from the UK was an attempt by the authors to discover a hard case for uncovering the 'us/them' dichotomy in that country's press. During the time period covered by the study, the UK was in the midst of a contentious public debate about the country's relationship with the EU, which ultimately culminated in Brexit, the withdrawal of the UK from the alliance. The Brexit movement was 
Table I. News stories analysed per media outlet.

\begin{tabular}{llr}
\hline Bulgaria $(n=83)$ & Standart & 48 \\
& Dneven Trud & 35 \\
Turkey $(n=65)$ & Cumhuriyet & 21 \\
& Hurriyet & 44 \\
UK $(n=57)$ & The Guardian & 57 \\
Total & & 205 \\
\hline
\end{tabular}

led by the UK Independent Party (UKIP), whose party manifesto includes the statement:

Rapid, mass uncontrolled immigration has been extremely damaging to Britain. We have imported cheap labour by the millions. This not only exploits migrants but depresses the wages and living standards of those at the bottom end of the economic scale, and drives up property prices and rental costs. (UKIP Policies - Immigration, 2021)

Because of the tight alignment of the UKIP movement with Britain's right-wing press and the party's frequently covered anti-migration appeals tangentially related to the Syrian refugees, the inclusion of those sources would surely increase the pool of articles, while shedding little light on the coverage of the actual refugee crisis. Thus, the inclusion of coverage from The Guardian, a newspaper known to be relatively sympathetic to refugees, created an opportunity to explore a maximum possible variation of characterization of the refugees in the most efficient and economical way possible.

To ensure a sufficient and manageable number of articles, we used the three constructed weeks per year sampling strategy, following Riffe et al.'s (2005) recommendations. Since the crisis was ongoing, we sought to capture a multi-year time period starting with the beginning of the civil war in 2011 through the end of 2014. We therefore randomly selected the days for the four different years and then added a $+/-2$ days as our sampling criteria, totalling 21 days from each year determined through an online random numbers generator. The purpose of using random dates was to ensure that our sample included different types of stories about Syrian refugees and did not skew results towards special dates or significant events. The online archives of the respective newspapers were examined through keyword searches that include the terms 'Syrian' and 'refugees' within the title or the main text of the news articles. As a result of this sampling process, a total of 205 news stories are included in this analysis. Table 1 gives details of the breakdown of news stories analysed per media outlet.

\section{Results and discussion}

\section{Actions and linguistic representations of refugees}

The first research question focused on actions attributed to the refugees in the news stories and the results reveal notable differences. The most frequent actions mentioned in Turkish news stories are actions involving violence and tragedy, such as: people killed, 
women raped, Syrian soldiers burning Sunnis' fields, fighting in Syria, beatings by State forces, subject to tank and bomb attacks, under fire, tortured, lost husbands in conflict, not eating anything for 5 days, being shot, children being kidnapped. The second most frequently used set of actions involve Syrian refugees being on the move. These include: climbed over wired fences, walked 17 hours, took children and ran away, escaped to Turkey, requested permission to cross the border, relocated inside their country, risked their lives to cross the Aegean. Another set of actions are related to refugee life in Turkey and these can be grouped under three main categories: camp life, negative aspects of camp life and life outside the camps. All these actions have a strong humanitarian appeal and emphasize the tragic conditions of Syrian refugees.

News stories from Turkey also often described actions involving camp visits by third parties and donations. It is interesting to note that the most mentioned third party is UNHCR Special Envoy and world-famous actress Angelina Jolie and the then United Nations High Commissioner for Refugees, Antonio Guterres, with most of the messages that the Turkish government was trying to emphasize being presented through them. Their actions include: being deeply affected by the heartbreaking stories of children suffering, visiting camps, playing, singing and having lunch with the children, giving gifts to the children, visiting refugees in container city, listening to their stories, crying, having pictures taken with refugee women, donating US\$100.000 and raising US\$5 million globally for refugees.

In contrast, the most frequent action described in the Bulgarian news coverage is by and large law enforcement detaining illegal refugees, typically by the border but sometimes within the country. The discourse was typically presented in a passive manner, with refugees being caught by the Bulgarian police and determined to enter the country illegally. They were then presented with options to be moved to a refugee camp, in most cases, or put in temporary refugee reception centres, or jails in some cases. The blatant use of the word 'illegal' and the more subtle verbs describing the 'capture' of the migrants created an underlying theme of criminality.

Another set of actions frequently described in the Bulgarian refugee coverage was improving conditions and facilities for refugees, including building additional centres to handle the increasing numbers, improving living conditions in existing refugee camps and building a border fence to minimize illegal crossings. An article from the Trud on 25 July 2014 states that 'We will always give them food and shelter, even if they do not need to live in the camps any more' and discussed how the conditions in the Harmanli camp had improved considerably over time, how more healthy food donated by a Canadian philanthropist was being delivered, featuring a photo of a little boy in the camp. Implicitly, this type of coverage acknowledges the need for more and better facilities while at the same time creating the impression that adequate steps are being taken and that the refugee crisis is being taken seriously.

By far the most common action associated with refugees in the UK news stories is concerned with victimization: being targeted for violence within Syria and fleeing from violence both inside Syria and across borders into locations such as Turkey, Jordan and Iraq. The flight of these refugees is often associated with negative impacts for non-refugee populations. Another action associated with refugees in the UK coverage is receiving or taking. Refugees receive aid in many forms: housing, food and education. They are 
rarely directly portrayed as grateful for the help, although that gratefulness might be assumed. However, their frustrations with aid are noted. Depicting refugees as recipients of aid puts them in a passive position, similar to the Bulgarian narrative. One unique aspect of the UK coverage was the refugees' portrayal as acting as unwitting pawns for Turkey's political ambition. The British coverage framed Turkey as 'other' within NATO, mentioning the Turkish desire to 'benefit' from the humanitarian crisis. Quoting a highranking Turkish official one article noted:

The big change in Turkey has been seeing its location as a boon, rather than a bind . . People would say, 'We live in the most difficult part of the world; we're always being beset with conflicts.' Now we see our geography as a strategic asset. (The Guardian, 9 June 2011)

\section{Main actors and discursive strategies across countries}

The second research question focused on the main participants/actors in the news stories, revealing structures of power and agency, and which discursive strategies are used to reflect their perspectives. The participants in the Turkish news stories were both grouped together and represented as collective nominal groups such as numbers, or they were individualized with the use of actual names of Syrian refugees and their personal accounts were highlighted. Collectivization is very common to news reports about refugees in Turkey and refugees are often referred to in large groups through numbers, figures and percentages, or quantified through metaphors of size and quantity. Some examples from the texts include: at least 1 million Syrians will come to Turkey, numbers will exceed expectations, a migration wave, an influx of refugees, 10,000 refugees waiting by the border:

Over 1,800,000 Syrians in Turkey. 1,600,000 ran away from Syria regime, 200,000 ran away from ISIS, 220,000 refugees in 22 camps in Turkey. Remaining 1.38 million people stay outside camps in border cities, 330,000 living in Istanbul. (Hurriyet, 16 October 2014).

In a few news articles, the individual accounts and actual names of Syrian refugees are provided when their tough escape, living conditions, or personal tragedies are underlined, such as: the 13-year-old boy Salih Agidi's heartbreaking story of losing his brothers, one brother dead, the other one fighting in Syria; the one millionth refugee, 19-year old mother of two, Büşra Osman; Murhaf, a young woman who lost her husband in the conflict; Şerife who lives in Turkey and her husband lives in Syria; Azize Abuzin living with her family of 9, staying in a room shared by 25 people. An article in Hurriyet, dated 15 June 2019, details the story of Talal el Luş, an escapee soldier who did not want to fight unarmed protestors, and explains the violence against individuals, such as people killed and women raped. While sharing personal stories opens up the possibility of revictimization of those telling them, such specific accounts also allow refugees to be present in the stories, giving them agency and power to tell their stories, however tragic they may be.

In contrast to the Turkish coverage, it was very rare indeed to tell any personal stories or disclose any personal details of the refugees who were captured in the Bulgarian articles. They are often lumped into a larger group and depicted only as a total number of refugees, 
sometimes mentioning the country of origin, or being grouped with their smuggler. When children, elderly or pregnant women were among the refugees mentioned in the article, there were never any personal details such as how this family ended up in Bulgaria and what kinds of reasons they had for escaping. The absence of personalization made it hard to associate the migrant with being victims in need of humanitarian assistance. This type of representation also removes the individuals from the tragedy, denying them any agency or chance to participate actively in the story. Even when humanitarian arguments were presented within the articles, they came at the end and were typically given by foreign or domestic NGOs. To summarize, individualization is completely absent from the Bulgarian media texts. Collectivization is very common as refugees are typically referred to by numbers and country of origin. It was common to refer to the influx of refugees as a 'wave' or a 'tide', implying a substantial and largely uncontrollable process.

Collectivization was also the most common approach to The Guardian coverage in the UK, heavily linked with quantification, thus denying refugees agency to recount their stories. Many stories ended with a list of 'official' counts: numbers dead, numbers enrolled in camps, numbers missing. This collectivization is underscored by a 'Live Updates' feature of The Guardian coverage, where up-to-the-minute updates from multiple Middle East locations were strung together in blog form. These short snippets pulled together headlines from disparate regions such as Syria, Turkey, Iraq, Egypt, Bahrain, Yemen and Libya, which underscored the 'collective' nature of the conflicts from the Western perspective. Collectivization is at times accompanied by the semantics of disaster: the scale of the tragedy is referred to as 'catastrophic', with refugees 'pouring' into surrounding countries. The refugees are themselves referred to as a 'fallout' of the sectarian conflict inside Syria.

There are also some instances of individualism in the UK coverage. When journalists were reporting from the front lines of the conflict, they usually included quotes from refugees and also from locals surrounding the camps. In one article, a widow from Homs shared the story of her escape from Syria with her small children after witnessing the murders of her husband and eldest son, presenting a personal story and an individual perspective, somehow granting them power and agency to their own story.

\section{Locations and spaces linked to Syrian refugees}

The third research question examined locations and spaces referenced in news stories. The locations commonly mentioned in the Turkish coverage are either inside or outside the camps. Camps, tent or container cities are frequently mentioned, sometimes specified by name such as Akcakale, Kilis Öncüpınar, or Reyhanlı camp, or through a geographical location such as a camp in Gaziantep, a Turkish border city. These news stories sometimes mention the services provided in camps such as schools and education centres for Syrian children, mosques, play areas, health services, etc. A few news stories focus on the daily life and challenges of refugees who live outside camps, in poor neighbourhoods of Istanbul or Gaziantep.

Another location often referred to in the news stories is the 'border' between Turkey and Syria. The border is mentioned in stories that explain its porous nature and how refugees cross the border, sometimes undocumented. One news story cites the opposition leader Kilıçdaroğlu who stated that the border is 'nonexistent' because of this constant movement of refugees back and forth (Cumhuriyet, 14 May 2013). Another story 
emphasizes the need to establish a 'safe zone' between Syria and Turkey that can safely house refugees and stop them from entering Turkey, but such accounts are quite rare. The borders of Iraq, Jordan, Lebanon and Turkey are mentioned as areas where Syrian refugees are constantly on the move.

There is no doubt that the location most commonly mentioned in the Bulgarian news stories is also a border, the border between Bulgaria and Turkey. It is mentioned in many of the news stories as the gate through which illegal migrants entered Bulgaria. Its porous nature was noted in reference to those refugees who crossed the border undocumented and were later captured; articles never covered the case of any refugee who entered the country legally.

Another location often referenced in the Bulgarian coverage is Harmanli refugee camp, the largest refugee camp in the country. It often served as a destination point where illegal immigrants will be moved to, in addition to the Ljubimets refugee centre and Elhovo camp. The Voenna Rampa centre in the capital Sofia is also mentioned in the coverage on a regular basis. A few articles describe refugee life within the camps, noting the poor living conditions, lack of resources and complaints by the residents. The complaints, however, were reported by international organizations such as Human Rights Watch but never by Bulgarian officials. Government representatives instead accused foreign NGOs of trying to vilify Bulgaria and defended their actions as doing the best they could. While most of the spaces where refugees lived were dark and perhaps depressing, there were a few articles that presented a brighter side of life in the camps. These stories feature children in educational groups or families celebrating either Muslim or Bulgarian holidays. One example is the celebration of a Kurdish holiday called Newroz (21 March), which was described as a traditional Persian celebration with specific foods, flowers, etc. Another interesting human-interest story was the mention of Syrian refugees thanking Bulgaria and paying tribute to the host nation by bringing flowers to the monument of Vasil Levski (national hero) in the capital Sofia.

Perhaps because of the remoteness of Syria to the UK, The Guardian coverage included a large number of geographical regions: inside Syria, in the surrounding countries (both in camps and in towns near them) and world capitals, where negotiations and decisions about refugees were taking place. The only time the UK itself became a geography within the discourse was in the potential sense, with discussion both for and against bringing Syrian refugees to the UK. At one point this became a very contentious issue, with the UKIP leader Nigel Farage initially saying the UK had a 'responsibility' to help refugees, but then going back on his support for persecuted Syrian Christians: 'Where on Earth are the Christians going to go? Christians are now a seriously persecuted minority ... they are under assault from all sides.' With that statement, Farage sought to appear concerned and engaged with the events in Syria, while still closing UK territory to Muslims (The Guardian, 31 December 2013).

\section{Recontextualization strategies: Substitution, rearrangement, deletion and addition}

The final research question investigated the recontextualization strategies used in news stories such as substitution, rearrangement, deletion and additions such as legitimation, evaluation and repetition in the coverage of Syrian refugees across the three nations. 
Substitution: A strategy to highlight or diminish. The first recontextualization strategy investigated is substitution. A close reading of accounts of the Syrian refugees in Turkey reveal certain substitution strategies used by journalists to highlight certain aspects while completely ignoring others. The first major substitution is substituting the perceptions and reactions of refugees - the actual users of the camps - with those of famous international figures. The constant focus on Angelina Jolie's and Antonio Guterres's accounts of camps, or those of Turkish politicians, rather than mentioning the residents' accounts of life in camps is an important editorial decision to make sure that the negative assessments of camp residents are excluded from public discussion. This discursive strategy removes the voices and perspectives of Syrian refugees from the news accounts, denying them agency and power to explain their own experiences.

Another common substitution strategy used in the Turkish coverage is substituting the past for current events. When Syrians are given voice, it is always about what happened back in Syria or what they have gone through before arriving in Turkey. Syrians' accounts of life in camps is substituted with what happened before, which results in a coverage of tragic events in the past before they arrived in Turkey rather than learning about what they are doing now or their future plans. The other major substitution is about the future of refugees. They are not granted agency in the news stories to talk about their own futures. Camps are presented as a temporary solution before peace and stability come to the region. News stories mention that refugees will go back to their countries in the future. However, not many news stories mention what will happen if they stay longer.

The first noteworthy substitution in the Bulgarian coverage is replacing the missing reactions of the refugees with the implied interpretations of the journalists. There were no interviews with the migrants yet the text often described them as confused, displeased, discontent. A good example here is the coverage of a hunger strike within a camp due to the slow processing of paperwork by the Bulgarian authorities. Despite a lack of interviews with either refugees or officials, the reasons for the strike were very clearly stated. Members of law enforcement are the ones providing reasons for refugees entering the country or explanations of what has happened to them. The most common actors granted agency are Bulgarian government officials speaking outside their offices in press briefing in Sofia. They were most frequently the faces and voices explaining what is going on with the refugee crisis in Bulgaria rather than refugees. The over-reliance on government representatives was compounded by the frequent use of photos and by the long quotes copied verbatim within the articles.

A significant recontextualization strategy in the UK coverage was the conflation of refugees with extremists, through rearrangement. This is done by including both groups in the same article despite the fact that one has little to do with the other. While not directly labelling refugees as terrorists, the rhetorical structure implies that somehow the refugee crisis is increasing the threat of extremism, so much so that Baghdad is asking for aid.

Deletion. When it comes to deletion as a recontextualization strategy, the daily accounts of how refugees live and how they support themselves is rarely explained in the coverage examined from the three countries. Another major omission from the coverage are the future aspirations of Syrian refugees. It is evident that Turkey is not the dream country 
for many, and they try to find ways to escape to Europe, even by means of dangerous sea crossings in flimsy dinghies. But the reasons for them wanting to leave Turkey are never explained. This seems to be a discursive strategy for asserting the power of the Turkish government in supporting them and influencing public opinion so that Turkish readers feel refugees are happy with the conditions with which they are provided. We see another problem related to granting agency to refugees where their future plans are never discussed. Lastly, although they are affected the most by the Syrian refugees on a daily basis, accounts of local people and how they feel about living with these populations are missing from the news stories, creating challenges related to representation and participation in media discourse.

Similar to the Turkish coverage, the daily life of a refugee in a camp in Bulgaria is never depicted in the coverage, which is a major omission since we do not get to hear their perspectives, revealing a lack of agency in the representation of refugee populations. Similarly, the reasons why they left their home country and went through Bulgaria are not discussed. There are some vague references to war and persecution through the quotes of international/EU officials, but we do not get to hear the refugees' voices on why they left and embarked on a dangerous journey. There are a few instances where Bulgaria is explained as being a transit country for reaching more affluent European nations such as Germany and Sweden. Those reasons again come from police or Bulgarian officials and represent another major deletion.

Addition: Legitimation strategy for accepting refugees. Another important addition as a recontextualization strategy is legitimation. Several news stories from Turkey include justifications by government officials for supporting Syrian refugees, reflecting their power over the refugee populations. The humanitarian aspect of supporting those in need is emphasized in many quotes, 'They had to flee their much beloved country, they had no other options, had to leave all their belongings and their homes behind. Turkey opened its doors to create a better life for them' (Hurriyet, 5 April 2012). Sharing their resources with their guests is another aspect highlighted: 'It is important to share our home and food with our guests during these hard times', Bilal Erdoğan, Hurriyet, 3 December 2014).

This usage of the term 'guest' has also been observed by Efe (2019: 54) who stated that it is generally preferred by 'government officials and newspapers close to the government', as it is in line with the government's open-door policy. The passivity of the refugees, their lack of agency to determine their present or future is emphasized by representing them as those that need our help, and further enhance 'the positive self-construction of Turkish actors' (p. 63). In the beginning, 'when the Turkish state accepted and legitimized Syrian refugees as "guests" (Erder, 2016: 127), Syrian refugees in Turkish media were represented as victimized guests, struggling to survive under temporary protection status. Turkish coverage mentioned humanitarian aid provided to refugees, which further reveals that they are covered from a humanitarian perspective (Sunata and Y1ldiz, 2018). This positive attitude started to change later in 2016 from 'guests' to viewing them as a 'burden' or even a 'threat', with the initial sympathy changing to 'xenophobia' (Nielsen, 2016: 103). Another important legitimation aspect in the news stories involves reasons for refugees refusing to stay in camps in Turkey. These range 
from overcapacity in camps, possible job opportunities in other cities and people with young daughters feeling insecure due to fears of sexual harassment. A major fear is that of sexual violence against women, a news story published in Hurriyet on 8 September 2013 stated: 'They will take our women', or 'I won't go to camps, they are raping women there.'

Power relations make themselves evident in the reporting of who has agency to help others. A large number of articles included legitimation by Bulgarian government officials about the way the crisis has been handled. It is common to rely on police or law enforcement for basic facts - without using direct quotes. Many articles reference the chief of police in the region or the border patrol on duty at the time. The contacts they provide, not surprisingly, legitimize any action taken in relation to refugees. Although not explicit, the coverage implicitly endorses and implies praise towards law enforcement officers who are working hard to catch illegal migrants entering the country. While a few articles mentioned international criticism about the treatment of refugees at the border and within the country, Bulgarian government officials refused to acknowledge any wrongdoing. Even when criticism was evidenced by NGO reports or witness statements, officials simply dismissed it as an attack or attempt to undermine their image from abroad. Occasionally, foreign actors or celebrities such as Canadian millionaire Young Barry or boxing legend Hollifield are mentioned in the articles - but those are exceptions rather than the rule.

Evaluation as a political strategy. Evaluation as an addition strategy used in the news stories is mainly around the issue of Turkey's support for Syrian refugees and it ranges from positive to negative evaluation. Many news stories suggest that Turkey is a generous host, addressing the humanitarian needs of an increasing number of Syrians, providing shelter, food, education materials, and so on. Many news stories praise Turkey's open border policy and suggest that even refugees without documents (visas) could cross the border. Turkey's Minister of Energy and Natural Resources Y1ld1z is quoted as saying: 'Syria is under tank and bomb attacks, can we close our borders? Can we say no don't come here, stay there and die. We need to help during these hard times' (Cumhuriyet, 19 July 2014). Many Turkish officials, such as Prime Minister Erdoğan, are quoted for their evaluation and assessment of Turkey's generous support. Erdoğan stated that Turkey is involved in Syria to bring back peace and prosperity to the region, claiming this is a humanitarian issue and he gives the example of 2-year-old Banyas, '(we) couldn't be silent when children are dying, we are using politics to save babies' (Cumhuriyet, 14 May 2013).

On a similar note, a significant proportion of the news stories include accounts of UNHCR special envoy Angelina Jolie and the High Commissioner for Refugees Antonio Guterres about Turkey's aid efforts and their assessment of the refugee camps in Turkey. These news stories usually include their evaluations of Turkey's aid efforts such as, 'best camp I've seen. Turkey is generous towards Syrians' by Jolie (Hürriyet, 13 September 2012), or 'I'm very happy about the condition of the camps and container homes. High quality services are provided to refugees' by Guterres (Hurriyet, 13 September 2012). Even the UN Secretary General, Ban Ki Moon is presented as praising Turkey's efforts and quoted saying: 'Turkey is among the top 5 countries who are shouldering the burden 
of refugees. The Security Council needs to act decisively and stop violence to protect civilians and innocent people' on World Refugee Day (Cumhuriyet, 20 June 2014).

The UK coverage recontextualized coverage through the addition of information about the intractability of the sectarian crisis within Syria's different Muslim factions, with the refugees as an unfortunate consequence. This moral evaluation structure frames the responsibility for the crisis as belonging to Islam itself, and characterizes the way the religion has developed in terms of early disputes about dogma and hierarchy. It also reinforces the idea that Islam cannot coexist with other religions. These critiques are presented as a background for the UK audience, who are not expected to understand Islam well enough to grasp such subtleties.

Repetition as emphasis of potential risks. An important discursive addition strategy used in the Bulgarian coverage is that of repetitions. Several articles repeat claims that 'there is no real terrorist threat' posed by the refugees, although fears about the potential threat are expressed in the article. Similarly, there is discussion of a potential outbreak of Ebola or another contagious disease, only to be refuted since there were no cases of the disease recorded in the camps. However, discussing the potential of a terrorist threat and the potential of a contagious disease serves to reinforce the idea that such dangers exist and are inextricably linked to the refugees who bring foreign attitudes and diseases, and thus need to be held under control. This is exemplified by the following headline from Trud (9 August 2014): 'There are no refugees infected with Ebola' and from Standart: 'There is no risk of terror' (20 November 2013). A recurring theme in the Bulgarian coverage was the need for more resources. Various actors emphasized that Bulgaria needs more help in dealing with the refugee crisis and is looking to the EU to continue to support and offer additional funds for the proper handling of the refugee crisis. The need to satisfy Brussels/EU requirements and follow EU rules and regulations was also often noted.

\section{Conclusions}

This study identifies discursive structures and journalistic practices related to three different governmental responses to the Syrian refugee crisis, revealing several key differences, including distinct terms used to refer to actions related to refugees, the main participants/actors in the news stories, and spaces and locations mentioned in the media coverage. Different recontextualizations of the refugee story were achieved through linguistic substitution, rearrangement, deletion and additions. Informed by Van Leeuwen's (2008) discourse as social practice, we can see that journalistic practice in all three countries is engaged in an ongoing dialogue with local governmental power structures, reflecting and amplifying their priorities. The specific cultural and political context allowed texts to legitimize the voices of different groups and maintain the power and agency of the local political elite by prioritizing their views and either excluding completely or marginalizing the perspective of refugees, thus disabling their participation in the media discourse. As stated by Mohd Don and Lee (2014), over-reliance on government officials, law enforcement or other authority figures serves to perpetuate the unequal power relations in society, and this is once more exemplified in this study. The 
prominence of political actors in news coverage, specifically political leaders, further 'legitimized the negative stereotypes of refugees' (Sajir and Aouragh, 2019: 557).

Although using the different discursive representations of the refugees, the national media in each country was able to create a dichotomy between 'us' - the people of the host country - and 'them' - the refugees. There was no significant difference between how the same topic was covered by two differently oriented newspapers published in one country, or the newspaper considered to be most sympathetic to the refugees' cause in another, and findings underscore the widespread journalistic tendency to 'otherize' refugees. A key finding of the study is that refugees are afforded little agency in any of the three countries' journalistic practices, largely portrayed as 'victims' or 'a threat'. While many stories clearly intended to invoke pity and empathy for the refugees, others are openly distrustful and associated refugees with crime, terrorism and a wide range of social problems. Individuals are rare in the coverage, erasing the refugees' humanity. En masse, refugees end up representing a problem to be solved. But the consistent treatment of the refugees as victims and outsiders is in dialogue with three different power structures and political agendas. Thus, in Turkey, we see the emphasis on visits from celebrities and international organizations meant to portray Turkey as an active partner in protecting their fellow Muslims, a 'testament to Turkish government and its might' (Bilge, 2019: 119), and acting as a metaphorical and physical bridge between Europe and the Middle East.

In contrast, the Bulgarian news coverage leverages the victimization and outsider status of the refugees to assert its rights within the country's somewhat fraught relations with its fellow EU states. By virtue of its geographical proximity to the crisis vis-à-vis the rest of the EU, Bulgaria was one of the frontlines of engagement with the refugees. This leads to coverage focused on maintaining law and order, and often its high costs. The articles discount accusations of the maltreatment of refugees, seeking to portray the government's actions as consistent with its EU colleagues. The British coverage of the crisis is in dialogue with a political system at a crossroads. Already confronting a wave of anti-EU sentiment among many of its citizens, the coverage seeks distance from the crisis. Thus, the victimization discussed in the British coverage, especially when quoting right-wing British politicians, is linked to Islam itself. Despite the significant British Muslim population, the scapegoating of Islam in the coverage seeks to create a cultural abyss between the UK and the refugees - and, in so doing, distancing the UK itself to a EU more willing to accommodate the refugees. This served to solidify the 'in-group' status of the British, and ultimately associated the refugees with another 'outgroup', at least as far as a significant portion of the British population was concerned: the EU. As noted by Innes (2010: 459):

Coverage of asylum seekers in British media - alienating an 'out-group' especially if that outgroup is within the state territory, solidifies the identity of the 'in-group' and this phenomenon is apparent in the securitization of migration within the European Union.

Locations emphasized in the coverage were consistent with those controlled by local power structures. The Turkish coverage emphasized camps where many Syrians were forced to settle for the long term. The Bulgarian coverage emphasized borders, as their 
main goal was to serve as a conduit, moving refugees out of their space and further into Europe. British coverage exoticized the turmoil by including a host of faraway destinations, only focusing on Britain as a location in the potential sense. And that was always portrayed in a negative fashion, never focusing on the country as a potential place of safety for refugees, but rather focusing on the potential disruption to the country if refugees were to arrive in large numbers. Similarly, while discursive structures and recontextualization strategies varied among the three journalistic traditions studied, they were all consistent in upholding the prevailing power structures in the countries in which they operated. Turkish coverage substituted opinions of high-ranking international NGOs and celebrities about camps for those of the actual refugees. Bulgarian coverage legitimized the country's handling of the crisis. British coverage rearranged the refugees, conflating them with extremists and terrorists.

In order to fully understand and deconstruct discourse, one needs to examine its relationship with power (Carabine, 2001). Thus, our finding of binary representations of 'us' versus 'them', can illustrate how the notions of nation and nationhood may inadvertently seep into media discourse. By positioning refugees, migrants and asylum seekers as outsiders, the news discourse denies them any agency, privileges the value and legitimacy of the host nation presenting it in a position of power, and potentially constructs a causal link between 'outsiders' and their innate propensity to destabilize, undermine or threaten the local community and their way of life. Despite the different discursive strategies used in the media of the three countries, they all rely on ideological polarization, depicting refugees as the 'other'. The anti-immigrant stance that was more prominent in the Bulgarian and British coverage seems inherently connected to the notion of national sovereignty as well as the importance of border control, as observed by Pugh (2004). It is no surprise then that the discourse of sovereignty tends to be employed as an exclusion strategy by the news media that portray refugees as 'illegal, foreign, deviant, and unknown - in other words, as a potential threat' (Mohd Don and Lee, 2014: 689).

What is the repercussion of this type of media coverage for the host nations as well as the refugees? In these times of increased forced migration, not only in Europe but also around the globe, shifting public opinion will be a key factor for the integration of displaced populations. In addition to affecting public attitudes, media coverage may also affect how politicians respond to right-wing rhetoric and what types of policies they develop and implement in order to advance social cohesion. Without evolving journalistic practices yielding agency over their stories to refugees, coverage will continue to reflect the priorities of existing power structures, adversely affecting their acceptance. One limitation of this study is a focus on text as a unit of analysis. Future research could integrate a multimodal analysis, analysing not only the images that accompany texts, but also examining placement, page layout, the use of headlines, text size, type and colour of lettering, and so on.

\section{Acknowledgements}

This research was supported by a Page Legacy Scholar Grant from the Arthur W. Page Center at the Bellisario College of Communications at Penn State University. Any opinions, findings and conclusions or recommendations expressed in this material are those of the authors and do not necessarily reflect the views of the Pennsylvania State University. 


\section{Funding}

The authors received no financial support for the research, authorship and publication of this article, and there is no conflict of interest.

\section{ORCID iD}

Emel Ozdora-Aksak (iD https://orcid.org/0000-0002-8818-7265

\section{References}

Aarssen N (2017) Re-orienting refugee representation? A multimodal analysis of Syrian refugee representation on the social media platform Humans of New York. Interdisciplinary Journal of Communication 9(2): 1-14. Available at: https://journals.sfu.ca/stream/index.php/stream/ article/view/229 (accessed 10 January 2021).

Baker P et al. (2008) A useful methodological synergy? Combining critical discourse analysis and corpus linguistics to examine discourses of refugees and asylum seekers in the UK press. Discourse \& Society 19(3): 273-306.

Berry M et al. (2015) Press Coverage of the Refugee and Migrant Crisis in the EU: A Content Analysis of Five European Countries. Prepared for the United Nations High Commissioner for Refugees.

Bigo D (2002) Security and immigration: Toward a critique of the governmentality of unease. Alternatives: Global, Local, Political 27(1): 63-92.

Bilge N (2019) Friend or foe: Cultural fusion theory and media coverage of Syrian refugees in Turkey. Communication, Culture and Critique 12(1): 110-127.

Bozdag C and Smets K (2017) Understanding the images of Alan Kurdi with 'small data': A qualitative, comparative analysis of tweets about refugees in Turkey and Flanders (Belgium). International Journal Of Communication 11: 24.

Bulgarian newspapers online (nd) Bulgarian newspapers | Bulgarian news. Available at: https:// www.w3newspapers.com/bulgaria/ (accessed 10 January 2021).

Bulgarian Statistical Institute (2020) International Migration by Citizenship. Available at: https:// infostat.nsi.bg/infostat/pages/reports/result.jsf?x_2=72 (accessed 10 March 2021).

Burr V (1995) An Introduction to Social Constructionism. London: Routledge.

Burscher B, Spanje JV and Vreese CHD (2015) Owning the issues of crime and immigration: The relation between immigration and crime news and anti-immigrant voting in 11 countries. Electoral Studies 38: 59-69.

Canetti-Nisim D, Ariely G and Halperin E (2008) Life, pocketbook, or culture: The role of perceived security threats in promoting exclusionist political attitudes toward minorities in Israel. Political Research Quarterly 61(1): 90-103.

Cap P (2017) Studying ideological worldviews in political discourse space: Critical-cognitive advances in the analysis of conflict and coercion. Journal of Pragmatics 108: 17-27.

Carabine J (2001) Unmarried motherhood 1830-1990: A genealogical analysis. In: Wetherell M et al. (eds) Discourse as Data: A Guide for Analysis. London: Sage.

Cukier W et al. (2008) A critical analysis of media discourse on information technology: Preliminary results of a proposed method for critical discourse analysis. Information Systems Journal 19(2): 1-22.

D'Appollonia AC (2012) Frontiers of Fear: Immigration and Insecurity in the United States and Europe. Ithaca, NY: Cornell University Press.

De Rycker A and Mohd Don Z (eds) (2013) Discourse and Crisis: Critical Perspectives, Vol. 52. Amsterdam: John Benjamins. 
Dimitrova D, Ozdora-Aksak E and Connolly-Ahern C (2018) On the border of the Syrian refugee crisis: Views from two different cultural perspectives. American Behavioral Scientist 62(4): $532-546$.

Eberl JM et al. (2018) The European media discourse on immigration and its effects: A literature review. Annals of the International Communication Association 42(3): 207-223.

Efe I (2019) A corpus-driven analysis of representations of Syrian asylum seekers in the Turkish press 2011-2016. Discourse \& Communication 13(1): 48-67.

Erder S (2016) Preliminary thoughts on the Syrian refugee movement. New Perspectives on Turkey 54: 119-130.

Esses VM, Medianu S and Lawson AS (2013) Uncertainty, threat, and the role of the media in promoting the dehumanization of immigrants and refugees. Journal of Social Issues 69(3): $518-536$.

Fairclough N (1992) Discourse and text: Linguistic and intertextual analysis within discourse analysis. Discourse \& Society 3(2): 193-217.

Fitzgerald J, Curtis KA and Corliss CL (2012) Anxious publics worries about crime and immigration. Comparative Political Studies 45(4): 477-506.

Gabrielatos C and Baker P (2008) Fleeing, sneaking, flooding: A corpus analysis of discursive constructions of refugees and asylum seekers in the UK press, 1996-2005. Journal of English Linguistics 36(1): 5-38.

Gibney MJ (2004) The Ethics and Politics of Asylum: Liberal Democracy and the Response to Refugees. Cambridge: Cambridge University Press.

Hoewe J and Bowe BJ (2018) Magic words or talking point? The framing of 'radical Islam' in news coverage and its effects. Journalism, October.

Humphrey M (2013) Migration, security and insecurity. Journal of Intercultural Studies 34(2): $178-195$.

Innes A (2010) When the threatened become the threat: The construction of asylum seekers in British media narratives. International Relations 24(4): 457-477.

Ivanova V (2018) The wages of fear: Attitudes towards refugees and migrants in Bulgaria. Foundation Institute of Public Affairs. Available at: https://ec.europa.eu/migrant-integration/ librarydoc/the-wages-of-fear-attitudes-towards-refugees-and-migrants-in-bulgaria (accessed 10 March 2021).

KhosraviNik M (2009) The representation of refugees, asylum seekers and immigrants in British newspapers during the Balkan conflict (1999) and the British general election (2005). Discourse \& Society 20(4): 477-498.

KhosraviNik M (2010) The representation of refugees, asylum seekers and immigrants in British newspapers: A critical discourse analysis. Journal of Language and Politics 9(1): 1-28.

Kirkwood S et al. (2016) The Language of Asylum: Refugees and Discourse. Chichester: Palgrave Macmillan.

Larsen MA (2008) North American insecurities, fears and anxieties: Educational implications. Comparative Education 44(3): 265-278.

Lawlor A (2015) Framing immigration in the Canadian and British news media. Canadian Journal of Political Science 48(2): 329-355.

MacroTrends (2021) Bulgaria Immigration Statistics 1960-2021. Available at: https://www.macrotrends.net/countries/BGR/bulgaria/immigration-statistics (accessed 10 March 2021).

McKinlay A and McVittie C (2011) Identities in Context: Individuals and Discourse in Action. Oxford: Wiley-Blackwell.

Mohd Don Z and Lee C (2014) Representing immigrants as illegals, threats and victims in Malaysia: Elite voices in the media. Discourse \& Society 25(6): 687-705. 
Nielsen YS (2016) Perceptions between Syrian refugees and their host community. Turkish Policy Quarterly 15(3): 99-106.

Onay-Coker D (2019) The representation of Syrian refugees in Turkey: A critical discourse analysis of three newspapers. Continuum 33(3): 369-385.

Parker S (2015) 'Unwanted invaders': The representation of refugees and asylum seekers in the UK and Australian print media. eSharp 23: 1-21.

Polat FÇ and Kaya E (2017) An othering practice: Attitudes to Syrian refugees in Turkey. Mersin Üniversitesi Sosyal Bilimler Enstitüsü e-Dergi 1(1): 38-48.

Pugh M (2004) Peacekeeping and critical theory. International Peacekeeping 11(1): 39-58.

Riffe D, Lacy S and Fico GF (2005) Analyzing Media Messages: Using Quantitative Content Analysis in Research, 2nd edn. Mahwah, NJ: Lawrence Erlbaum.

Sajir Z and Aouragh M (2019) Solidarity, social media, and the 'refugee crisis': Engagement beyond affect. International Journal of Communication 13: 550-577.

Shirazi F (2013) Social media and the social movements in the Middle East and North Africa: A critical discourse analysis. Information Technology and People 26(1): 28-49.

Sohoni D and Sohoni TWP (2014) Perceptions of immigrant criminality: Crime and social boundaries. Sociological Quarterly 55(1): 49-71.

Sturge G (2019) Migration statistics: How many asylum seekers and refugees are there in the UK? Available at: https://commonslibrary.parliament.uk/insights/migration-statistics-how-manyasylum-seekers-and-refugees-are-there-in-the-uk/ (accessed January 2021 ).

Sunata U and Y1ldiz E (2018) Representation of Syrian refugees in the Turkish media. Journal of Applied Journalism \& Media Studies 7(1): 129-151.

Tavassoli F, Jalilifar A and White PR (2019) British newspapers' stance towards the Syrian refugee crisis: An appraisal model study. Discourse \& Society 30(1): 64-84.

Tong J and Zuo L (2019) Othering the European Union through constructing moral panics over 'im/migrant(s)' in the coverage of migration in three British newspapers, 2011-2016. International Communication Gazette 81(5): 445-469.

Turvill W (2020) BBC was biggest news website globally in early April as new figures suggest interest in Covid-19 has peaked. Press Gazette. Available at: https://www.pressgazette.co.uk/ biggest-news-websites-april-2020/ (accessed 7 January 2021).

UK Independence Party (2021) UKIP Policies, Immigration. Available at: https://www.ukip.org/ ukip-policies/immigration (accessed).

UNHCR (2020) Planning Summary Report. Available at: https://reporting.unhcr.org/sites/default/ files/pdfsummaries/GA2020-Turkey-eng.pdf (accessed January 2021).

UNHCR (nd) Refugees and Asylum Seekers in Turkey. Available at: https://www.unhcr.org/tr/en/ refugees-and-asylum-seekers-in-turkey (accessed March 2021).

Van Dijk T (1987) Communicating Racism: Ethnic Prejudice in Thought and Talk. London: Sage.

Van Dijk TA (1998) Ideology: A Multidisciplinary Approach. London: Sage Publications Ltd.

Van Dijk T (2001a) Critical Discourse Analysis. In: Schriffen D et al. (eds) The Handbook of Discourse Analysis. Oxford: Blackwell, 349-371.

Van Dijk T (2001b) Multidisciplinary CDA: A plea for diversity. In: Wodak R and Meyer M (eds) Methods of Critical Discourse Analysis. London: Sage, 95-120.

Van Dijk T (2005) Contextual knowledge management in discourse production: A CDA perspective. In: Wodak R and Chilton P (eds) A New Agenda in (Critical) Discourse Analysis. Amsterdam: John Benjamins, 71-100.

Van Leeuwen T (2008) Discourse and Practice: New Tools for Critical Discourse Analysis. Oxford: Oxford University Press.

Willig C (2013) Introducing the Qualitative Research in Psychology, 3rd edn. Maidenhead: Open University Press. 
Yaylacı FG and Karakuş M (2015) Perceptions and newspaper coverage of Syrian refugees in Turkey. Migration Letters 12(3): 238-250.

\section{Author biographies}

Emel Ozdora-Aksak is Assistant Professor in the Department of Communication and Design, Bilkent University.

Colleen Connolly-Ahern is Associate Professor, Advertising and Public Relations Senior Research Fellow at the Arthur W. Page Center for Integrity in Public Communication, and Associate Editor, Journalism \& Mass Communication Quarterly, Bellisario College of Communications, Penn State University.

Daniela Dimitrova is Professor in the Department of Communication Iowa State University, and Editor of Journalism \& Mass Communication Quarterly, Iowa State University. 